\title{
The Application of Micro-lectures in College English Teaching and Learning
}

\author{
Yuan-zhen Peng \\ English Department, North China Electric Power University, Baoding, Hebei Province, PRC
}

\begin{abstract}
This paper attempts to make an analysis of the advantages and disadvantages of micro-lecture when being employed in the process of College English Teaching and Learning. Furthermore, some suggestions are put forward for the sake that English teaching and learning can be improved efficiently in China by incorporation of information technology.
\end{abstract}

Index Terms - micro-lecture, interest, interaction, self-study

\section{Introduction}

Micro-lectures or micro-courses or micro-lessons are usually considered to be a five-minute to eight-minute short movie-like video program. The length of time is supposed to be less than ten minutes and it is designated to vividly illustrate and clearly explain one thing with pictures and sounds. It is advised that College English teachers employ micro-lectures to assist students with the preview and review of the knowledge they will learn or have acquired in class. Warm-up activities would be replaced by learning microlessons before class. Micro-lectures can be also used as assignments for students to get acquainted with after class.

\section{A. A Review of Definitions}

The original form of micro-lecture was initially proposed in both the 60-second Course by LeRoy A. McGrew (1993) at University of Northern Iowa and One Minute Lecture proposed by T.P. Kee (1995) at University of Leeds. The present heatedly-discussed concept of micro-lecture was put forward in 2008 by the advanced teaching and learning designer David Penrose from San Juan College in Farmington, which consists of five steps: list the core task or concept to be dealt with; offer background information for the task or concept; prepare a one-to-three-minute video based on the background information; design questions to lead students into exploring the knowledge they will learn and tasks after learning the material in class; upload the video and corresponding tasks to the courses management system.

In China, many well-known scholars-Hu Tiesheng in the Educational Information and Network Technology Center of Foshan Bureau of Education, Professor Jiao Jianli, Professor Li Jiahou, and Professor Zhang Yichun, have given definitions about micro-lectures. They define micro-lectures as a short video program lasting for a few minutes and illustrating one topic or one point.

\section{B. Features of College English Micro-Lectures}

College English textbooks are made up of eight or ten units. Each unit consists of two sections: Section $A$ and Section B, which are concerned with a common topic, and more emphasis is attached to the former one with a more detailed analysis and more relevant exercises including vocabulary, structure, translation and writing. Listening and Speaking Courses textbooks are the similar case, dealing with a common topic and including certain conversations and passages for listening practice and speaking activity. The underlying concept of the series of textbooks is that their aim is to equip students with knowledge and language skills in class and to reinforce what has been learned by doing homework after class. The major task of a teacher is to explain the materials and exercises in the textbooks. Students always sit, listen, take notes and get ready to answer questions. NonEnglish majors set certain time for English study. It is unpractical to assign many hours to College English courses inconsiderate of requirements for their majors. The dilemma is that College English teaching and learning is a continuous process. Students are supposed to be exposed to the language every day. It is not sufficient for students to attend classes and do a limited number of exercises. It is desirable for them to keep in touch with English whenever it is available. Microlecture is undoubtedly a good solution to the problem. Students can have access to the materials whenever and wherever. It is celebrated that micro-lecture is a video. Students are immersed in native language environment by listening and watching. They can imitate the pronunciation and intonation. It is much more convenient to take English with you through micro-lectures. English has become an international language. It is necessary for college teachers and students to commit time to it.

Another characteristic of College English teaching and learning is that there are approximately 50 students in one class, more than one hundred sometimes in certain course. Facing such a large class, teachers usually design the class as a teacher-centred one: no interaction between teachers and students or one or two questions for students to answer. Consequently, students do other things or homework of other subjects, to which teachers and students have been accustomed. After graduation, when it is time to use English, students regret more or less about wasting time on computer games or wasting time in classes. They even have a desire to learn English when working. It is not uncommon that the 30s and $40 \mathrm{~s}$ devote their spare time to English studies with a stronger motive and determination. Micro-lecture is also of great significance for us to learn English when we realize the need and feel the desire to learn. It is very likely that we can review words and keep listening to authentic English all along, that is to say, we can really be exposed to English whenever we have time. 
In addition, texts in College English textbooks centre on topics like education, love, cultural differences, and society. Exercises focus on the usage of words and expressions. Those topics are hot issues but it is strange students are not given time to discuss due to their reluctance to participate in class activities which leads to awkward situations owing to silence or involvement of only a small proportion of the class. Exercises are supposed to act as a means to review and reinforce the words and expressions students should master. The reality is that students do not care much about the reading materials in the text and exercises attached to the texts because they see little relation they have to the Band Four or Six tests except vocabulary they need to memorize to handle future tests. Listening materials and exercises are another issue. The young students have access to many multimedia English materials on the Internet. It is not advisable for students to do listening exercises for one hour continuously which easily lead to sleepiness. However, listening in class is far from sufficient to improve English listening ability, let alone speaking competency. Therefore, micro-lectures can be taken advantage of to keep students practicing listening to English every day. In this way their listening ability can be improved after one semester or one academic year.

In view of the features of College English teaching and learning and the drawbacks revealed in its process, it is strongly recommended that micro-lecture be bravely and initiatively employed in its process to arouse students' interest in English study and to promote the efficiency of College English teaching and learning.

\section{Advantages of Micro-Lecture in College English Teaching and Learning}

\section{A. Freshness and Vividness}

Before moving into the study of a following text, teachers tend to give the students the task of previewing it, which means reading the passage and having a general idea about its main content and outline. Some students turn a blank eye toward such homework; some students obviously forget it; some students are hindered by the appearance of new words; and a few hard-working students make efforts to accomplish it. Even those hard-working students only stay on the level of getting familiar with the materials before coming to the class. They are ready to follow the teacher to learn the meaning and usage of some new words and expressions. They are sometimes proud if they can answer some difficult questions. For example, they can put a Chinese sentence into English without making grammatical mistakes. Micro-lecture is designed to change these teaching and learning habits. Previewing task is to watch a video, which is usually done in the warming-up activity in traditional classes. Students can watch the video with native pronunciation and intonation and expressions more than once. They are put in an oral English environment. It is not silent anymore. At the beginning, language is acquired in a manner just as a child learns his native tongue ever since he was born. Students will be excited about such task. If a student is not good at English, he or she can get prepared for class activity by learning the video more than once until they fully comprehend it. By learning the micro-lecture repeatedly, students can pose any question that comes into their mind in the previewing process. Teachers then have their homework to do: get prepared to answer the questions or to design questions for students to discuss in class activities. In fact, not only the background knowledge can be presented in the micro-lecture, but the main idea, the general structure, the language points and the exercises can be explained in micro-lecture. So each unit or each text can be studied by listening to or watching the micro-lectures.

It is noticed that every student takes their cell phones wherever they go. Even in class they cannot help looking at their phones from time to time. Since they cling to the phone so much, these micro-lectures can be accessed or downloaded into their intelligent phones. They can access the information everywhere with interest. Anytime they have a question they can put forward for a solution or a discussion. Therefore, the traditional class is dismissed. The role of the teacher is replaced by micro-lecture transmitted by cell phones and Internet. Then what will teachers do in such flipped classes? They will not be useless as some people worry. They will act as a person to pose questions, answer questions and to assist students in the acquisition of English, just like a walking stick. The class is returned to the students again. Teachers are not taken as a knowledge carrier, but the Internet or the microlecture is.

Another important point has to be mentioned here. When students learn English, there are underlying assumptions related to the social and psychological culture of the target language. Students cannot receive any information as a container. English is yet acquired as a tool to communicate with the outside world. There are a countless number of cultural factors to learn and taken account into. Class time is limited. Micro-lectures concerning one cultural difference can be made to illustrate the difference vividly and directly.

\section{B. Economy and Efficiency}

Micro-lectures are an economical and efficient way for students to learn something centering around one topic repeatedly. Students can watch or listen to them time and time again if they want to or have time to. Classes are devoted to discussions, presentations, questions and answers. Classes change into meetings. Input and output are interwoven. Reading, listening, speaking or even writing is given equal emphasis, in fact. Once you have previewed for the class discussions or presentations or reviewed for the examinations by taking advantage of micro-lectures, you are prepared to talk in class or to write on the examination paper. Class time is an exciting time. No student will have the time or the opportunity to do other things. They come to classes to share ideas.

Micro-lectures reduce the time that students spend on taking notes in class. Traditionally, teachers take on the role to convey knowledge in class and students are supposed to listen attentively and be busy taking notes in class. After class, diligent students are more likely to review the notes. For other students, the incomplete notes may become draft papers, 
nothing valuable. Before examinations, notes are borrowed form the diligent students or the teacher. Students cram for the examinations by reviewing and memorizing the notes. Microlectures can save much time for students. Micro-lectures can not only help students preview materials, but also can assist students review the materials topic by topic. Is it all passive? The answer is definitely no. Instead, if effective micro-lectures are integrated into courses, teachers are required to meet a higher standard rather than only telling the students the information or knowledge in the textbooks, and students are supposed to learn more before coming to the classroom or after leaving it rather than just taking notes or memorizing what the teacher has given. Both teachers and students are active all along in the whole process of input and output, in which thinking plays an important role. Thanks to the promotion of active thinking power in the process of teaching and learning, its efficiency can be greatly improved. In addition to less time in class and more knowledge, what has been achieved is the mechanism of thinking, reasoning, and questioning.

\section{Visualization and Operability}

Micro-lectures are usually videos, so it is not hard to agree on the benefits in visualization and operability. For instance, how to teach the pronunciation of the 26 letters or the pronunciation of vowels and consonants? Traditionally, we listen to tape recordings and imitate the pronunciation, the verbal explanations contributing little to the result, or we carefully observe the shape of the teacher's mouth when he or she pronounces a vowel or a consonant in a slow and dramatic way in order for students to watch it clearly and imitate it correctly. Nowadays, if there is a micro-lecture dealing with a certain group of vowels or consonants, beginners can watch it clearly and again and again. The task of the teacher is to check whether the student has done it in a correct way. Students can make use of their spare time to practice. As a result, class time offers teachers and students to meet and see what the student has accomplished out of class and what difficulty he or she has while studying it on his or her own. The application of microlectures can relieve teachers of a huge workload.

\section{Repetition and Recurrence}

The most obvious advantage of micro-lectures is that they can be played time and time again. It is much more convenient for students to minutely study one knowledge point with the help of micro-lectures. There is an old Chinese saying, "gain new knowledge by reviewing old." It is the same case when it comes to English study. By watching the micro-lectures carefully, we can imitate the pronunciation and intonation until it becomes natural for us to speak like a native English speaker. Furthermore, the recurrence of certain words and language points helps us remember them automatically as we study the micro-lectures once and once again. If we study via our cell phones, we can be exposed to English all time. The amount of exposure time influences whether we can think in the English way ultimately. It means that the more exposed we are exposed to the English environment, the more likely we are to be accustomed to the English way of expressing our ideas, thoughts and feelings.

\section{Disadvantages of Micro-Lectures in College English Teaching and Learning}

Although there are undoubtedly many advantages of incorporating micro-lectures in College English teaching and learning, the disadvantages can not simply be ignored. Multimedia programs replace books. Some scenes can substitute words. Is there any difference between watching videos and reading books? Is watching videos as active as reading books? It is admitted that watching TV does harm to children's learning ability because they are only receiving information or knowledge without thinking or with little thinking. Then the question arises whether there is any difference between watching micro-lectures and watching TV.

\section{A. Pieces of Information or Knowledge}

A micro-lecture is short video program. The systematic knowledge is divided into different pieces. Micro-lectures are intended to illustrate one topic or one knowledge point. It is suitable that students learn them one by one continuously. Once students forget their interest and lose the strength to continue, what they have got would be pieces of knowledge. They have obtained some knowledge and then they can use this part or that part. Nevertheless, they lack a systematic study of the knowledge in one subject. University students are regular ones. In China, they live on campus and can totally devote themselves to receiving higher education. It seems that micro-lectures cannot totally replace the class where teachers and students meet. Teachers as the giver of scores have the authority to supervise students and the ability to inspire them as well. Otherwise, students will stop learning without interests any more. Micro-lectures are useful to familiarize students with the new knowledge but the systematic study has to be carried out in class or by reading a series of books recommended by teachers.

\section{B. Fatigue}

It is not good for our health to watching programs on the computer or the mobile phone for a long time, especially harmful to our eyesight. The length of time for micro-lectures is less than ten minutes, which should be viewed as one of its advantages, because if we watch a program too long, we tend to get tired and have to take notes while watching in case we forget some interesting parts. Although watching videos are more appealing to youngsters, it is easier to get us exhausted mentally. We are reluctant to open a book, for words are much less attractive to our eyes. However, words can keep us in an active state mentally. It is beneficial to develop our intelligence and reasoning ability. Therefore, micro-lectures are not the only way to help students study by themselves before class and after class.

by reading a series of books recommended by teachers.

\section{Resistance from Teachers}

Traditionally, teachers give lectures and students take notes in class. Students are supposed to admire their teachers 
for their broad knowledge and deep thoughts. The majority of College English teachers are females, who are innately not passionate about the use and manipulation of machines. So the widespread use of micro-lectures depends on whether there are corresponding micro-lectures related to texts to rely on at present.

\section{Effects and Consequences}

The most striking effect is that students become the center of class and teachers become an assistant and facilitator to students in their learning process. At the same time, learning moves to the center by replacing teaching. Teachers teach based on the need and interests of students. The question here is whether what students are interested in and need is what they are supposed to learn. So teachers are not completely directed by students' interests. What students watch in microlectures are planned in advance. Micro-lectures are given by teachers, definitely aimed at what is to be achieved in class.

A question arises here that how micro-lecture is integrated into the teaching and learning of English literary works. Some factual information like background information about the author and the works can be presented through video. Students can learn and appreciate it time and time again if they are interested in. It is best if it is spoken by English native speakers. In fact, literature courses are demanding for teachers and students. Background introduction is accomplished out of class. The class is devoted to questions and answers and interactions. Therefore, it is necessary to read the literary works. That is to say, micro-lectures are another form to attract students to preview or review. It certainly doesn't mean that it is the only efficient way for students to study out of class.

\section{Conclusions}

Micro-lectures are another interesting and colorful means for students to access information and knowledge. Youngsters, especially the males, are enthusiastic about learning knowledge through multi-media programs. Micro-lectures can bring many benefits and challenges to students and teachers in College English. Students come to class not with notebooks to write words down on. They cannot just sit there and listen to the teacher. They have to bring their questions and ideas to class. Teachers are supposed to answer different questions from students, not just giving lectures without taking students' opinion into consideration. The form of assignments and classes has altered. The form has changed from reading books or materials to watching videos. Classes have been given to both students and teachers instead of only the teacher who dominates the speech.

\section{References}

[1] Dong Jianqiao, "Educational application of information technology and foreign language classroom," in Media in Foreign Language Instruction 82. 2001, pp46-49.

[2] Hu Tiesheng, Huang Mingyan, and Li Ming, "The three stages of microlecture development and its enlightenment," in Journal of Distant Education 217. 2013 (4), pp.36-42.

[3] Kee, T.P. "The one minute lecture," in Education in Chemistry, 32. London: Royal Society of Chemistry, 1995, pp100-101,

[4] McGrew, L.A. "A 60-second course in Organic Chemistry," in Journal of Chemistry Education, 70. Washington: American Chemical Society, 1993 (7), pp. 543-544.

[5] Zhang Jinlei, Wang Ying, and Zhang Baohui, "Introducing a new teaching model: flipped classroom," in Journal of Distant Education 211. 2012(4), pp.46-51. 